\title{
Guidance Behind Criticisms: The Good Parenting as Portrayed in the First Malay Autobiography
}

\author{
Rahimah Hamdan ${ }^{1} \&$ Arba'ie Sujud ${ }^{1}$ \\ ${ }^{1}$ Department of Malay Language, Faculty of Modern Languages and Communicaton, Universiti Putra Malaysia, \\ Selangor, Malaysia \\ Correspondence: Rahimah Hamdan, Department of Malay Language, Faculty of Modern Languages and \\ Communicaton, Universiti Putra Malaysia, 43400 UPM Serdang, Selangor, Malaysia, Tel: 603-8946-8939. \\ E-mail: rahimahh@upm.edu.my
}

Received: December 5, 2018

Accepted: January 14, 2019

Online Published: January 30, 2019

doi:10.5539/ass.v15n2p116

URL: https://doi.org/10.5539/ass.v15n2p116

\begin{abstract}
This paper was aimed at identifying the guidance to parenting that emerged in the first Malay autobiography, the Hikayat Abdullah, and subsequently, to analyse those instructions on parenting in the context of the traditional Malay society of the $19^{\text {th }}$ century. The recognition accorded to Abdullah Munshi as the Father of Modern Malay Literature has attracted various reactions from scholars. Some scholars regard Abdullah Munshi as the one who brought renewal to Malay literature through his courageous criticism of the customs and culture that had been in practice for generations. On the other hand, there are scholars who disapprove of that recognition being given to him and who consider Abdullah Munshi's criticisms in his works as a deviation from the reality expressed in previous works. Nevertheless, not a single study has suggested that perhaps Abdullah Munshi firmly emphasized those criticisms with the intention of providing some sort of guidance. Hence, by analysing certain texts in the Hikayat Abdullah and by reviewing the evidence from the perspective of Swettenham (1895), who objectively evaluated the thinking and culture of the Malay community, this study was able to rectify the image of Abdullah Munshi, who, all this while, was considered to be pro-British because of his harsh criticism of the Malay community. Moreover, those criticisms were meant to provide guidance for the family institution, especially for parents. This indirectly proves that Abdullah Munshi took a serious view of parenting and believed that improvements were necessary to produce a dignified and civilized generation. In conclusion, the autobiography, the Hikayat Abdullah, was not just a new form of writing that deviated from the conventions of traditional Malay literature, but was the fruit of the wisdom of the author that was meant to benefit his readers.
\end{abstract}

Keywords: guide, parents, autobiography, Abdullah Munshi, Hikayat Abdullah

\section{Introduction}

'The deed of the reed pen' refers to deep-rooted Malay literary activities following the arrival of Islam to this region (Braginsky, 1989; 1993, p. 1). Starting from here, the Malay community became aware of the importance of literature in their life, which was termed by Braginsky $(1993 ; 2001)$ as 'literary self-awareness'. Now, in order to produce a literary work several criteria had to be met to fulfil this 'literary self-awareness' such as the objective, purpose, essence, facts and type so that the modus operandi for the creation of literary works would become increasingly clear. This view was first put forward by Syed Muhammad Naquib al-Attas (1972, p. 49), who was of the opinion that Islam is a religion that is responsible for sparking a 'spiritual revolution' that can transform the view of life (weltanschaunng) and values of the Malays dating back to the $14^{\text {th }}$ century, from the old to the new, from myth to reality, from the traditional to the modern, based on rationalism, individualism and internationalism. As a result, the Malay Literature corpus has been coloured with diverse genres such as literary books, tales of the prophets and warriors of Islam, legends, historiographies, legislations, epics and so on, that, on the whole, were not left out from that 'literary self-awareness'. In order to fulfil that 'literary self-awareness' in their writings, Malay authors incorporated in their works elements aimed at educating and teaching.

However, the period from the $17^{\text {th }}$ to the $19^{\text {th }}$ century saw the spread of Dutch and British colonialization into the Malay World, which led to a clash of cultures and thinking between the East and the West. It was during this time that the colonialists started to collect the local literary works and to study them in order to facilitate their management of the communities in their conquered colonies. Finally, the colonial scholars concluded that these 
Malay literary works were filled with imaginary elements and were of no benefit whatsoever to their readers (Wilkinson, 1907). Therefore, it was necessary to introduce new genres, such as the autobiographies genre, which were becoming increasingly popular in the West, to mark the importance of their colonization in benefitting the colonies (Wilkinson, 1907; Winstedt, 1940). In response to this, Abdullah Munshi's name was introduced, and he was bestowed with the title of "Father of Modern Malay Literature' for his courage in challenging the literary conventions that had been passed down for generations (Hamdan, Sujud, \& Radzi, 2016).

\section{Literature Review}

Abdullah Munshi's appearance, initially as a teacher and translator of the Malay language to the British, brought a new phenomenon into the Malay literary world. Due to his familiarity with the colonialists, he was easily influenced by the trend of realism that they were introducing (Hamdan, Sujud, \& Affendi, 2016). It was obvious that this trend fought for a manifestation of the realities of human life without mixing in mythical and supernatural or transcendent elements (Rani, 2006, p. 343). These changes were a 'cultural shock' to the conventional Malay writers in particular, and the entire traditional Malay society in general (Skinner, 1978). Abdullah Munshi courageously transformed the conventional Malay literature by introducing a new style of writing. This Western style of writing, which was characterised by reality and deviated from the conventional form that had been passed down, led to the composition of the travelogue, Kisah Pelayaran Abdullah, in 1838 and the first Malay autobiography, Hikayat Abdullah in 1842 (Hamdan \& Bahri, 2014a). Alfred North (Skinner, 1978) praised Abdullah Munshi work as follows, "[...] a work of singular interest in beautiful Malay, and in all respects a new thing in the language". Later, Wilkinson (1907) acknowledged the superiority of Abdullah Munshi's work, and he eventually called him 'the pioneer of modern Malay Literature'. As a consequence, the Hikayat Abdullah became a source of reference for English cadets in their efforts to understand the worldview and the values that were upheld by the Malay community. Several other colonial and local scholars also acknowledged the courage of Abdullah Munshi in challenging the literary conventions, and they went on to introduce new and innovative works (Rahimah Hamdan \& Shaiful Bahri (2014b). These included works such as Glimpses into Life in Malayan Lands in 1864 by Thomson, and works by Winstedt (1940), Za'ba (1940), Skinner (1959), A. Bakar Hamid (1979), Johns (1979), Yahya Ismail (1987), Kassim Ahmad (1981), Mohd. Taib Osman (1988), Muhammad Hj. Salleh (1988) and several others, who were of the opinion that Abdullah was a critical and free writer, who was not shackled by his patrons and did not simply magnify the ruler, as the other Malay writers had been doing at that time. Starting from here, modern elements were introduced that finally led to a new phenomenon in Malay literature (Hamdan, Sujud, \& Adnan, 2018).

However, the recognition accorded to Abdullah Munshi as the 'Father of Modern Malay Literature' was rejected and even criticised by several other scholars such as Syed Muhammad Naquib al-Attas (1969; 1971), Sweeney and Phillip (1975), Hassan Ahmad (1976), Sweeney (1980), and Ungku Maimunah Mohd. Tahir (2001) [to just name a few], who believed that Abdullah Munshi only continued with the literary tradition in his historiographical work Sejarah Melayu, which was acknowledged by the $17^{\text {th }}$ century author, Hamzah Fansuri, for its 'individualism, inner self-expression, creative use of language and its ambiguity'. Ungku Maimunah (2001) called for a more in-depth assessment of the recognition given to Abdullah Munshi by stating that the Malay community was forced to accept a 'Father of Modern Malay Literature' who had produced works that were 'characteristically non-literary'; (Maimunah 2001; Hamdan \& Sujud, 2016). Darus Ahmad (1965:9) expressed a similar sentiment when he defined 'literature' as "essays in the form of letters or books that are beautiful, good and beneficial. In other words, literature is a collection of books written in a beautiful language and with good content." This view was reinforced by Abdul Rahman al-Ahmadi, who defined 'literature' within the conventions of Malay writing as a collection of good essays, written in a beautiful language and having a good content (1966:3). Therefore, 'with good content' and 'having a good content' point to the benefits that the works can bring to their readers regardless of their social standing or the institution to which they belong.

The question is, is it true that Abdullah Munshi's Hikayat Abdullah is a 'non-literary' work? Is not 'literature', according to the conventions of Malay writing, 'something that can be of benefit to its readers?' Moving on from these views, this study examined Abdullah Munshi's criticisms of the community in his magnum opus, i.e. the Hikayat Abdullah (2008). Were these criticisms in reality a guide for the purpose of educating by means of sarcasm? Why was Abdullah Munshi so critical of the Malay family institution in his works? On reviewing highlights in previous works, it was found that not a single study interpreted Abdullah Munshi's criticisms as being capable of educating or guiding, and neither did they make the family institution the focus of their research Hence, the objective of this study was to identify the guidance to parenting contained in the first Malay autobiography, the Hikayat Abdullah, and to analyse that parenting guide in the context of the traditional Malay society of the $19^{\text {th }}$ century. 


\section{Methodology}

This study employed the text analysis approach on the Hikayat Abdullah in an effort to indirectly repair the image of Abdullah Munshi, who all this while has been regarded as being pro-British because of his harsh criticism of the Malay community. In order to achieve the first objective, which was to identify the guidance to parenting in the first Malay autobiography, this study used the Hikayat Abdullah (2004) and discovered three categories of parenting guidelines that were not taken seriously by the community, namely:

(i) Parents need to show the best example (model)

(ii) Parents need to understand the concept of knowledge

(iii) Parents need to understand the concept of teachers in the acquisition of knowledge

Meanwhile, to achieve the second objective, the parenting guidance was analysed in the context of the traditional Malay society of the 19th century based on the worldview and the values that embraced by them, as noted by several colonial scholars, among them being Raffles (1835), Swettenham (1895), Wilkinson (1907), and Winstedt (1940), who wrote extensively on the thinking and values that prevailed in the colonial society. However, this study chose the perspective by Swettenham (1895) in his book, Malay Sketches, because this work reported comprehensively and objectively on the initial reaction of the colonialists towards the Malay community. In addition, only Swettenham reported on his experiences of interacting directly with the Malay community when he became the first British Resident in the Federation of Malaya. Although Swettenham was more negative than positive in his attitude towards the Malay community, nevertheless, this colonial perspective was in line with the criticisms by Abdullah Munshi (Cohn, 1996). This was exemplified by the view expressed by Swettenham (1895, p.vii) regarding the character of the Malays, as given below:

"This is not a book of travels, nor is it, in even the smallest sense, the record of traveller's experiences in a foreign land. It is a series of sketches of Malay scenery and Malay character drawn by one who has spent the best part of his life in the scenes and amongst the people described".

\section{Results}

Children are pure by nature when they are born into this world. Their attitudes and behaviours are very much influenced by their environment, which plays a major role in the formation of their adult personality. The Malay society takes a serious view of the concept of 'parenting' to the extent that it has triggered proverbs such as 'Bapa borek anak rintik' (like father like son) and 'Bagaimana acuan, begitulah kuihnya' (the cake fits the mould). This shows that the family institution is held in such high regard by the Malay community that it is even expressed in their literature. Darling and Steinberg (1993) went on to define 'parenting procedures or guidance' as:

"[...] a constellation of attitudes toward a child that are communicated to the child and that, taken together, create an emotional climate in which parent's behaviours are expressed. These behaviours include both the specific, goal-directed behaviours through which parents perform their parental duties (to be referred to as parenting practices) and non-goal directed parental behaviours, such as gestures, changes in tone of voice, or the spontaneous expression of emotion".

The above excerpt clearly shows that the behaviour of the parents is an early model for stimulating the cognitive and emotional development of children until it is reflected in their personalities (Hamdan, 2017). Taj Us-Salatin (1966:147) made mention of the importance of safeguarding the trust given by Allah SWT in these words, "[...] the son is to replace his life and it is the son who will give life to his name, such that nothing can be taken away from his care". Thus, it is clear from this traditional work (constitutional literature) that 'children are a reflection of their parents'. Their good or bad behaviour depends on the education and upbringing they received from their parents. As such, this study examined the criticisms in the Hikayat Abdullah, especially with regard to the family institution, and proved the truth behind his criticisms based on the perspective of Swettenham (1895), a colonial scholar who closely observed the culture and thinking of the Malay community.

\subsection{Guide to Parenting in The Hikayat Abdullah}

Swettenham $(189$, p. 1) gave several tips on how to win the hearts of the Malays such as by living with them, speaking their language, respecting their religion, enjoying their jokes, being sympathetic and helping them in their difficulties and sharing in their joys (Swettenham, 1895, p. 1). Such actions would increase the trust of Malay individuals and ultimately, it would be easier to manipulate them. This was the very transparent and biased perspective of Frank Swettenham, which he expressed in the preface to his book, Malay Sketches (1895), which succeeded in proving his credibility as a colonial administrator and scholar. 
In that regard, an examination of the Hikayat Abdullah revealed that three guides were contained in the combination of criticisms levelled by Abdullah Munshi against parenting, namely, that parents need to show the best example, parents need to understand the concept of knowledge, and parents need to understand the concept of teachers in the acquisition of knowledge. The details are as follows:

\subsubsection{Parents Need to Show the Best Example}

Abdullah Munshi's earliest criticism in the Hikayat Abdullah (2004) had to do with the attitude of Malay parents in not doing frequent checks of their every action (2004, pp. 1-2). According to him, such an attitude will have a negative impact on the psychological and emotional development of their children. Hence, the parenting guide that can be extracted from Abdullah Munshi's criticism is that every parent should be tolerant and have an 'open attitude'. This will be reinforced by their status as the best model for their children. The attitude of not checking on their every action may result in them running 'amok', which, according to him, was synonymous with the Malay community. If this attitude is not handled in a rational manner, it can result in 'casualties', as mentioned by $\operatorname{him}(1895$, p. 3) below:

"A Malay is intolerant of insult or slight; it is something that to him should be wiped out in blood".

The Hikayat Abdullah also criticised the religious beliefs of the Malays, who were easily shaken because of their lack of faith. Abdullah Munshi began to question the responsibility of parents until finally, he wrote these words of wisdom as a guide for parents, "[...] if you are humble, ask of the noble; if you are poor, ask of the rich; and if you lack in understanding, ask of God (Hikayat Abdullah, 2004, p. 2). Abdullah Munshi's criticism was actually a guide to his community, especially the family institution, if it had been interpreted in detail. For example, the other instruction concerning parenting was, "do not lose hope in Allah swt" (Hikayat Abdullah, 2004, p. 9). Being an author who always felt responsible for his community, Abdullah Munshi could sense that the upbringing of children was a great test for parents. It was for this reason that he criticised those parents who stayed away from their religion and instead placed all their hopes in and prayed to supernatural beings that would ultimately lead them astray. Swettenham's $(1895$, p. 3) description of the Malay individual, "He is a Muhammadan and a fatalist, but he is also very superstitious", is proof of the above statement.

Abdullah Munshi further reinforced this superstitious element that was deeply embedded in the society. For example, the belief of parents that if a child was always falling sick or was suffering from a chronic illness, then it meant that the child's name was too 'heavy' for him or her to bear (Hikayat Abdullah, 2004, p. 12). What was even worse was that if a child was constantly ill, then, it was a sign that it was not compatible for the child to be raised by the parents. According to the Hikayat Abdullah (2004, p. 11), it was believed that it would be better for the child to be sold to a family with many children. Abdullah Munshi vehemently criticised this practice because according to him, this culture appeared to encourage parents to give up and not to believe in the Qada and Qadar of Allah swt (Hikayat Abdullah, 2004, p. 11). Abdullah Munshi was of the view that such beliefs caused the Malays to be backward in their thinking and affected the quality of their parenting, and especially, the family institution that was being built. These beliefs also included the use of charms and amulets, which was rampant among the Malays (Hikayat Abdullah, 2004, p. 51). Abdullah Munshi tried to convey to parents the importance of being faithful to their religion so as to win the favour and enjoy the blessings of Allah swt upon the home. Based on this phenomenon, Swettenham (1895, pp. 4-5) censured the majority of the Malay Muslims who were impervious to the Christian teachings being preached to them by the European missionaries, when in reality, this was because they had a poor understanding of their own religion, as mentioned in the statement below:

"Though the Malay is an Islam by profession, and would suffer crucifixion sooner than deny his faith, he is not a bigot; indeed, his tolerance compares favourably with that of the professing Christian, and he thinks of these matters at all, he believes that the absence of hypocrisy is the beginning of the religion".

The Malay community was described by Abdullah Munshi was one that strongly believed that all illnesses were caused by ghosts and demons. That was why many parents sought the help of medicine-men or traditional healers if the family came down with any illness. This act was obviously criticised strongly by Abdullah Munshi in the Hikayat Abdullah (2004, pp. 110-111). He went on to instruct parents to accept in their souls that all illnesses were according to the will of Allah SWT and were not, as they had believed for generations, caused by supernatural powers. Parents are individuals who are capable of changing the perception of their children in order to get rid of these superstitious beliefs and to replace them with a high dependence on Allah. It is Allah who answers all the prayers of His servants, even though they stray from the teachings of Islam, because Allah is by nature Most Gracious and Generous (Hikayat Abdullah, 2004, pp. 110-111). Swettenham (1985, p. 228) proved this when he came out with a 'hard' statement as follows:

"[...] people whose ancestors had for generations belonged to the place and who were saturated with 
ancient customs. Prejudices and superstitions that had to be learned, and with many of which it was difficult to sympathise".

\subsubsection{Parents Need to Understand the Concept of Knowledge}

Abdullah Munshi criticised parents who were not concerned about providing their children with knowledge. He described how, as a child, he used to be envious of the Malay children of his age who happily played and enjoyed their childhood, while he was forced to sit at his studies the whole day. Indirectly, Abdullah Munshi was instructing parents to teach their children from an early age to cherish knowledge, especially knowledge of the Al-Quran. In fact, children should learn to sketch because this will eventually train them to write well (Hikayat Abdullah, 2004, p. 13). Abdullah Munshi continued to give other instructions such as parents need to force their children to write or copy verses from the al-Quran because if they are trained diligently, they will be able to write beautifully (Hikayat Abdullah, 2004, p. 25). In fact, parents need to train their children to recite the al-Quran at the mosque. This is because the mosque is the centre where theologians and Islamic law experts gather, and they will definitely be able to help correct any mistakes made during recitations by those in attendance (Hikayat Abdullah, 2004, p. 24). What is interesting is that Abdullah Munshi called on his community, especially parents, to ensure that they understand the translation of the al-Quran and not just read it. The Malays need to change their practices because the interpretation of the translated al-Quran will help to enhance their understanding of Islam. This was stressed by Swettenham (1895, p. 6) when he stated that:

"Until he is fifteen or sixteen, this atmosphere of a better world remains about him. He is often studious even, and duly learns to read the Koran in a language he does not understand".

Abdullah Munshi criticized his community for being closed-minded with regard to knowledge, especially when it came to the mastery of foreign languages other than their own mother tongue. He instructed parents, especially, to encourage their children to master many languages, even the languages of the non-Muslim communities (Hikayat Abdullah 2004, p. 101). By learning these foreign languages, the Malay community can go forward in tandem with the other advanced races of the world. Furthermore, through their mastery of foreign languages, the Malays will be able to master foreign knowledge that can benefit their country (Hikayat Abdullah, 2004, pp. 42-43). However, according to Abdullah Munshi, learning the language and knowledge of foreigners would be more meaningful if it began with the mastery of their own language first, which could be acquired by reading books on Malay legends (Hikayat Abdullah, 2004, p. 36, 96). In other words, Abdullah Munshi called on his people, especially parents, to give priority to gaining proficiency in their own language first among the children and to continue to open their minds to delve into foreign languages so that they will not be put down by other individuals. The statement by Swettenham (1895, p. 218) below, clearly demonstrates how a colonialist belittled the cultural heritage of the Malays with regard to the relationship between the ruler and his people. There is no other way for the Malays to correct this except to master their language (English) as well as the knowledge introduced by them in order to explain this confusion with constructive and rational arguments. For example, Swettenham (1895, p. 218) misunderstood the 'language of the court' as follows:

'In this feudal and conservative country when the people eat, they 'makan', but the Raja does not 'makan', with him it is 'santap'. When the 'masses' bathe they 'mandi', but the same operation in the case of a Raja is called 'siram' [...] Education and contact with European will alter all this, and in the next century there will be more equality and probably less politeness and fraternity. But then also there will be no royal preserves, no class privilege, and no state junketings where noble and peasant meet in generous rivalry of skill with a single desire to snatch from the toil, the disappointments, and the sorrows of life one week of pleasure wherein individual joy may grow greater in the knowledge that is shared by many".

\subsubsection{Parents Need to Understand the Concept of Teachers in the Acquisition of Knowledge}

The most important matter in the acquisition of knowledge is the respect of teachers. The blessings of learning are gained through this action. In this regard, Abdullah Munshi advised parents to understand the concept of 'teachers' and 'tutoring' in the acquisition of knowledge (Hikayat Abdullah 2004, p. 16). He emphasised that a teacher deserves the right to punish his students, especially if they violate the school rules. This is because the punishment will serve to teach, educate and discipline them. Teachers cannot be charged for meting out punishment, but instead, parents should trust them fully with the education of their children. The Hikayat Abdullah (2004, p. 20) clearly states that teachers should be trusted completely when it mentions, "Do whatever is necessary as long as their hands and feet are not broken". Abdullah Munshi's experience below of being punished by a teacher explains this situation:

"So, it became my task every night to go and show the names of those people. Even so, I was slapped and shamed several times. If any of the names were not spelled correctly, these names were hung around my 
neck to humiliate me. This went on for about a month until I was finally able to write all the names correctly". (Hikayat Abdullah, 2004, p. 28)

The above situation was akin to the Malay proverb 'to bend a bamboo, start when it's still a shoot'. The Hikayat Abdullah (2004, pp. 23-24) also listed several physical forms of punishment aimed at teaching a lesson about the commission of a wrongdoing in the hope that the child will not repeat the offence again. This was the concept of education that should be accepted by parents in their efforts to groom their children to become useful members of society in the future, as shown in Table 1 below:

Table 1. Instruments of punishment

\begin{tabular}{ll}
\hline Instrument of Punishment & Offence \\
\hline Cane and Chinese clamp (apit cina) & For children who stole or hit their classmates \\
Stock (kayu palat) & For children who escaped from studying, climbed trees and kicked their friends \\
Iron chain & $\begin{array}{l}\text { For children who played truant or were always quarrelling or who did not listen } \\
\text { to instructions and were late for lessons. }\end{array}$ \\
\hline
\end{tabular}

Table 1 shows that the traditional Malay society meted out heavy punishments based on the type of offence that was committed. For example, a pupil who stole or hit his classmate in the school grounds would be punished with the 'cane' and 'Chinese clamp'. The 'Chinese clamp' was made from four pieces of rattan, each about six inches in length. The pieces were fitted together at one end, while the other end was threaded with a long piece of twine. The fingers of the pupil would be wedged between the pieces of rattan and squeezed together. Any pupil who escaped from studying, climbed trees or kicked his friends would be placed in the stock. This 'stock' was made of wood about the width of a man's chest, with three (3) holes pierced through it (left, centre, and right). A cord was passed through the centre hole and knotted at the left and right holes. The child's feet were placed in the loops of the cord, which were then twisted upwards. The soles of the offending pupil were then beaten. Meanwhile, the final punishment for playing truant, quarrelling, refusing to listen to the instructions of the teacher and being late for lessons was the 'iron chain'. The iron chain, which was about six feet long, was nailed to the top end (head) of a beam, while the free end was locked. The pupil's hips were locked with the 'iron chain' and he was made to carry the wooden beam round the school compound.

Table 2. Punishments based on actions

\begin{tabular}{ll}
\hline Punishment & Offence \\
\hline Squat and rise holding the ears (singgang) & Not listening and being naughty \\
Suspended over smoke & Lazy in studies \\
Tied to a post & Making mistakes in class \\
Hung from both hands & Fighting, running away and stealing \\
Flogged on the buttocks & Naughty and running away \\
Rubbing pepper in the mouth & Telling lies and insulting people \\
\hline
\end{tabular}

Table 2 below illustrates some of the more severe punishments that were imposed on students based on the offence that was committed. For instance, students who did not listen to their teachers were subjected to the punishment known as 'singgang', where the student had to hold his left ear with his right hand and his right ear with his left hand, and he would then be asked to stand up and sit down over and over again. Students who were lazy and always making mistakes in their studies or lessons would be suspended over smoke or tied to a post. The former punishment was imposed by burning dry coconut fibre and then suspending the child over the smoke. For the latter punishment, the student would be tied to a post and had to read from his slate until he was able to read smoothly. The punishment was different for students who fought, ran away from school and stole. Such students were hung from both hands or flogged on their buttocks. Students who used foul language, told lies and constantly insulted people would have their mouths rubbed with pepper.

Tables 1 and 2 present the punishments mentioned in the Hikayat Abdullah (2004, pp. 23-24), which were aimed at teaching a lesson to students who were guilty of committing such offences. These penalties were to ensure that the students listened to instructions and were diligent in their schoolwork. This was something that parents had to accept for the sake of their children's future and they should not ignore or deny the ability of teachers to shape the generations to come. Swettenham (1895, pp. 3-4) mentioned several Malay individuals, the majority of whom were illiterate and had not received a proper education. Thus, it was not surprising that they were not interested in knowledge and failed to understand the concept of 'teachers' and 'tutoring'. Therefore, Abdullah Munshi's criticism of his community as being 'sick' and in need of change was accurate. The statement below by 
Swettenham (1895, pp. 3-4) proved that the Malay community had no love for knowledge, but preferred rather to waste their time on entertainment and thoughtless activities:

"[...] he is fond of gambling, cock-fighting and kindred sports [...] while he looks askance on all innovations, and will resist their sudden introduction. [...] The Malay has often been called treacherous. [...] he is courteous and expects courtesy in return $[\ldots] "$.

\section{Conclusion}

A review of Abdullah Munshi's criticisms in his book, the Hikayat Abdullah, was appropriate to clear the bad 'image' accorded to him when he was labelled as being pro-British. Most of his criticisms were directed more toward the weaknesses of the family institution, especially on parenting. According to this study, the reality behind the criticisms was that Abdullah Munshi was trying to provide some guidance so that positive changes could take place in his community.

This study was able to achieve its main objective, which to identify the guide to parenting in the first Malay autobiography, the Hikayat Abdullah. Three categories of parenting guidance were found, namely parents need to show the best example (model), parents need to understand the concept of knowledge, and parents need to understand the concept of teachers in the acquisition of knowledge. Meanwhile, the second objective, which was to analyse the guide to parenting in the context of the traditional Malay society of the $19^{\text {th }}$ century, was proven through excerpts from the book titled Malay Sketches (1895), which was written by Frank Swettenham, the colonial administrator of the Straits Settlements, based on his observations of the thinking and culture of the Malay community. To summarize, Abdullah Munshi's works deserve further study so that the negative perceptions of him can be remedied. Furthermore, being an individual who was the closest to the British colonialists, Abdullah Munshi must certainly have been aware of the schemes of the colonialists when it came to the residents of the colonies, and knowing that it was a delicate matter, he needed to deal with it wisely. The 'constructive' statement below by Swettenham (1895, p. 3) should be evaluated in a more rational manner from a post-colonial perspective so that a fairer assessment can be made of the natives:

"Malaya, land of the pirate and 'amok', your secrets have been well guarded, but the enemy has at last passed your gate, and soon the irresistible Juggernaut of Progress will be penetrated to your remote fastness, slain your beasts, cut down your forest, 'civilized' your people, clothed them with strange garments, and stamped them with the seal of a higher morality".

\section{References}

Abdullah Abdul Kadir, M. (2004). Hikayat Abdullah. Kassim Ahmad (Ed.). Kuala Lumpur: Yayasan Karyawan. Ahmad, D. (1965). Persuratan Melayu. Penang: Sinaran Bros. Bhd.

Ahmad, H. (1976). Sastera Melayu Moden Semenjak Munshi Abdullah. Dlm. Anwar Ridhwan (Ed.). Di Sekitar Pemikiran Kesusasteraan Malaysia 1957-1972 (pp. 284-302). Kuala Lumpur: Dewan Bahasa dan Pustaka.

Ahmad, K. (1981). Kisah Pelayaran Abdullah. Kuala Lumpur: Fajar Bakti.

Ahmad, Z. A. (1940). Moden Developments. Journal of the Malayan Branch of the Royal Asiatic Society, 17(3), 142-162.

Al-Attas, S. M. N. (1969). Preliminary Statement on a General Theory of the Islamization of the Malay-Indonesian Archipelago. Kuala Lumpur: Dewan Bahasa dan Pustaka.

Al-Attas, S. M. N. (1972). Islam dalam Sejarah dan Kebudayaan Melayu. Universiti Kebangsaan Malaysia.

Bakar Hamid, A. (1979). Diskusi Sastera, Jil.II: Kesusasteraan Moden. Dewan Bahasa dan Pustaka.

Braginsky, V. I. (1989). Sistem Sastera Melayu Klasik dan Penilaiannya. Dewan Sastera, Oktober, 42-51.

Braginsky, V. I. (1993). The System of Classical Malay Literature. Leiden: Koninklijk Instituut Voor Taal-, LandEn Volkenkunde Press.

Braginsky, V. I. (2001). The Comparative Study of Traditional Asian Literatures: From Reflectives Traditionalism to Neo-Traditionalism. Surrey: Curzon Press.

Cohn, B. S. (1996). Colonialism and Its Forms of Knowledge: The British in India. Princeton University Press.

Darling, N., \& Sternberg, L. (1993). Parenting Style as Context: An Integrative Model. Psychological Bulletin, 113, 487-496. https://doi.org/10.1037/0033-2909.113.3.487

Hamdan, R. (2017). The Ethics of Nurturing Children in Traditional Malay Literature. Man in India, 97(24), 41-55. 
Hamdan, R., \& Radzi, S. B. M. (2014a). Hero of Two Ages: Mohd. Said Sulaiman as the First Malay Autobiography Editor. Asian Social Science, 7(10), 191-199. https://doi.org/10.5539/ass.v10n7p191

Hamdan, R., \& Radzi, S. B. M. (2014b). The Meaning of Female Passivity in Traditional Malay Literature, Asian Social Science, 10(17), 222-228. https://doi.org/10.5539/ass.v10n17p222

Hamdan, R., \& Sujud, A. (2016). "An Author's Relationship with His Audience”: The Earliest Autobiographical Work of a Local Malay. The Social Sciences, 11(18), 4511-4522. https://doi.org/10.3923/sscience. 2016.4511.4522

Hamdan, R., Sujud, A., \& Adanan, N. F. (2018). Abdullah the Priest and His Advice Based on the Al Quran and Hadith. International Journal of Civil Engineering and Technology (IJCIET), 9(7), 1566-1574.

Hamdan, R., Sujud, A., \& Affendi, N. R. N. M. (2016). Perspective of Abdullah Munshi as the Father of Modern Malay Literature. Journal of Scientific Research and Development, 3(7), 73-77.

Hamdan, R., Sujud, A., \& Radzi, S. B. M. (2016). The Emergence of Autobiography in Malay Literature. The Social Sciences, 11(5), 654-660. https://doi.org/10.3923/sscience.2016.654.660

Hussain, K. M. (1966). Taj Us-Salatin. Kuala Lumpur: Dewan Bahasa dan Pustaka.

Ismail, Y. (1987). Sejarah Sastra Melayu Moden. Kuala Lumpur: Fajar Bakti.

John. A. H. (1979). The Turning Image and Reality in Malay Perceptions of the Past. In A. Reid, \& D. Marr, Perceptions of the Past in Southeast Asia. Singapore: Heinemann Educational Books (Asia) Ltd.

Maimunah, U. (2001). Between Content and Aesthetics: 'Modernity' in the Writings of Abdullah Munsyi, the Acclaimed Father of Modern Malay Literature. Dlm. Fadillah Merican dan Ruzy Suliza Hashim (Eds.). Native Texts and Contexts: Essays with Post Colonial Perspectives (pp. 61-69). Bangi: Universiti Kebangsaan Malaysia.

Osman, M. T. (1988). Moden Malay Literature. In M. H. Salleh (Ed.), An Anthology of Contemporary Malaysian Literature (pp. 281-293). Kuala Lumpur: Dewan Bahasa dan Pustaka.

Raffles, S. (1835). Memoir of the Life and Public Services of Sir Thomas Stamford Raffles, F.R.S.\& c. \& c. Particulalrly in the Government of Java, 1811-1816 and of Bencoolen and Its Dependencies, 1817-1824; with Details of The Commerce and Resources of The Eastern Archipelago, and Selections from His Correspondence. London: James Duncan.

Rahman al-Ahmadi, A. (1966). Pengantar Sastera. Kelantan: Pustaka Aman Press.

Rani, M. Z. A. (2006). Kehadiran Barat dan Kesannya Terhadap Kesusasteraan. Jurnal Pengajian Melayu, 17, 330-361.

Salleh, M. H. (1988). An Anthology of Contemporary Malaysian Literature. Dewan Bahasa dan Pustaka.

Skinner, C. (1959). Prosa Melayu Baharu. London: Longmans, Green \& Co. Ltd.

Skinner, C. (1978). Transitional Malay Literature: Pt 1, Ahmad Rijaluddin and Munshi Abdullah. BKI 134: 466-487. https://doi.org/10.1163/22134379-90002582.

Sweeney, A. (1980). Reputations Live On. An Early Malay Autobiography. Berkeley: Univ.of California Press.

Sweeney, A., \& Phillips, N. (1975). The Voyages of Mohamed Ibrahim Munshi. Kuala Lumpur: Oxford University Press.

Swettenham, F. A. (1895). Malay Sketches. London and New York: John Lane.

Wilkinson, R. J. (1907). Malay Literature, Part 1. Romance, History, Poetry. Papers on Malay Subjects. The Federated Malay States Government Press.

Winstedt, R. O. (1940). A History of Malay Literature, with a Chapter on Modern Developments by Zainal Abidin bin Ahmad. Journal of the Malayan Branch of the Royal Asiatic Society, 17(3), 1-243.

\section{Copyrights}

Copyright for this article is retained by the author(s), with first publication rights granted to the journal.

This is an open-access article distributed under the terms and conditions of the Creative Commons Attribution license (http://creativecommons.org/licenses/by/4.0/). 